\title{
Effect of Cell Density on the Removal of Microcystis by Coagulation
}

\author{
Joo Eun $\operatorname{Han}^{\oplus} \cdot$ Wontae Lee $^{\dagger \oplus}$ \\ Department of Environmental Engineering, Kumoh National Institute of Technology
}

(Received May 21, 2020; Revised June 22, 2020; Accepted June 23, 2020)

Objectives: This study evaluated the removal of Microcystis by coagulation in raw waters with three different cell densities.

Methods : Raw waters were prepared at three different cell densities (target cell densities of 10,000, 100,000, and 1,000,000 cell/ $/ \mathrm{mL}$; actual cell densities of $9,950,102,000$, and $991,000 \mathrm{cell} / \mathrm{mL}$ ) by adding Microcystis into surface water from Nakdong river. Jar-tests were conducted with PACL, alum, illite, and loess at dosages of 0-150 mg/L.

Results and Discussion: Regardless of coagulant types, the removal rates of Microcystis increased as the coagulant dosages increased. PACl and alum exhibited higher removal rates than illite and loess; PACl was the best coagulant to remove Microcystis. Removal of chlorophyll-a was highest when $\mathrm{PACl}$ added at $20.4 \mathrm{mg} / \mathrm{L}$, and no significant increase in removal rate was observed with higher dosages of PACl. However, removal rates of chlorophyll-a by illite and loess gradually increased as the dosages increased.

Conclusions: With the coagulants tested in this study, removal rates of Microcystis increased as the coagulant dosages increased. Removal rates of Microcystis increased as the cell densities increased probably because Microcystis acted as particles which could enhance the coagulation efficiency.

Key Words: Cyanobacteria, Algal Bloom, Microcystis, Coagulation, Cell Density 


\title{
연구논문
}

\section{응집처리 시 Microcystis 조류 밀도가 제거효율에 미치는 영향}

\author{
한주은 ${ }^{\circledR} \cdot$ 이원태 $^{+}$
}

금오공과대학교 환경공학과

목적 : 낙동강 녹조현상시 가장 많이 발생되는 Microcystis를 세 가지 조류 밀도로 구분하여 응집처리에 의한 제거 특성을 조사하였다.

방법: 낙동강에서 채수한 원수에 배양한 Microcystis를 주입하여 세 가지 조류 밀도(목표 $10,000,100,000$, $1,000,000 \mathrm{cell} / \mathrm{mL}$, 실측치 $9,950,102,000,991,000 \mathrm{cell} / \mathrm{mL}$ )로 만들고 응집제 종류(PACl, Alum, 일라이트, 황토) 및 주입량 $(0 \sim 150 \mathrm{mg} / \mathrm{L})$ 을 달리하여 제거율을 파악하였다.

결과 및 토의: 응집제 종류와 관계없이 주입량이 증가할수록 Microcystis 제거율이 증가하는 경향을 보였으며, 같은 주입량에서는 PACl과 Alum의 Microcystis 제거율이 일라이트와 황토의 제거율보다 높았다. Microcystis 제거에 가 장 효과적인 응집제는 $\mathrm{PACl}$ 이였다. 클로로필a 제거의 경우 $\mathrm{PACl} 20.4 \mathrm{mg} / \mathrm{L}$ 주입 시 높은 제거율을 나타내었고 주 입량을 증가시켜도 제거율에 큰 변화가 없었던 반면 일라이트와 황토는 주입량을 증가시킬수록 클로로필a의 제거 율도 지속적으로 증가하였다.

결론: 조류 밀도와 관계없이 응집제 주입량이 증가할수록 Microcystis 제거율이 증가하는 경향을 보였으나, 조류 밀도가 낮은 경우 $(9,950 \mathrm{cell} / \mathrm{mL})$ 보다 높은 경우 $(102,000,991,000 \mathrm{cell} / \mathrm{mL})$ Microcystis가 입자성 물질로 작용해 응 집에 의한 제거율이 상승하였다.

주제어 : 남조류, 녹조 현상, 마이크로시스티스, 응집, 조류 밀도

\section{1. 서론}

정부의 수질보전을 위한 노력에도 불구하고 다양한 비점 오염원에서 유출되는 질소, 인과 같은 영양염류로 인해 하 천이나 호소 등에서 조류(Algae)가 생성되고 있다. 우리나 라의 경우 계절적 특성상 매년 여름철이 되면 수온이 상승 되어 조류가 서식하기 좋은 환경이 조성됨에 따라 호소 및 하천에서 조류(Algae) 과다증식 및 녹조현상(Algal bloom) 이 발생되고 있다. ${ }^{1,2)}$ 더불어 지구온난화로 인한 기후 및 강 우패턴 변화에 의해 가뭄과 홍수의 반복이 일어나 조류 발 생이 점차 가속화되고 있다. ${ }^{3)}$

조류가 수계에 대량으로 증식하게 되면 수계의 용존산소 (DO) 농도 감소, 맛·냄새 문제, 조류기인 독성물질 발생, 투명 도 저하 등의 다양한 문제를 발생시킨다.,5) 특히, 조류에서 기 인하는 이취미 물질인 Geosmin과 2-MIB (2-Methylisoborneol) 는 흙냄새, 곰팡내, 풀냄새 등의 냄새를 유발하여 수돗물의 불신 및 신뢰성 저하의 원인을 제공할 수 있어 먹는물수질 감시항목의 심미적 영향물질로 지정되어 관리되고 있다. ${ }^{6}$
또한 남조류 중 일부 종에서는 간독, 신경독 및 피부독 등 여러 종류의 독소를 생성하여 수생태계 및 가축 건강성 등 에 영향을 미치는 것으로 보고되고 있다. ${ }^{7-13)}$

조류(Algae)는 전 세계적으로 약 4,000종이 있는데 크게 남조류(Blue-green algae; Cyanophyceae), 녹조류(Green algae), 규조류(Diatoms; Bacillariophyceae) 등의 분류군으로 구분 할 수 있다. ${ }^{14)}$ 이 중 부영양화 수역에서 주로 녹조현상(Algal bloom)을 일으키는 식물플랑크톤인 남조류는 ${ }^{15)}$ 우리나라 상수원의 안전성 확보를 위해 하천과 호소의 조류 발생정 도를 확인하는 조류경보제의 지표로 사용되고 있다. 유해 남조류 4종인 Anabaena, Aphanizomenon, Microcystis, Oscillatoria 속의 세포수 합을 산정하여 단계별로 경보를 나누어 실시하고 있으며 ${ }^{16,17)}$ 단계별 발령기준은 관심( 1,000 세포 $/ \mathrm{mL}$ 이상 10,000 세포 $/ \mathrm{mL}$ 미만), 경계 $(10,000$ 세포 $/ \mathrm{mL}$ 이상 $1,000,000$ 세포 $/ \mathrm{mL}$ 미만), 조류대발생 $(1,000,000$ 세포 $/ \mathrm{mL}$ 이상 $)$, 해제 $(1,000$ 세포 $/ \mathrm{mL}$ 미만)로 나누어 상수원 구 간에 대해 관리하고 있다. ${ }^{18)}$

그동안 하천 및 호소의 조류를 제거하기 위하여 응집기술 
Table 1. Characteristics of raw water from Nakdong river.

\begin{tabular}{cccccccc} 
Parameter & $\begin{array}{c}\mathrm{pH} \\
(-)\end{array}$ & $\begin{array}{c}\text { Turbidity } \\
(\mathrm{NTU})\end{array}$ & $\begin{array}{c}\mathrm{UVA}_{254} \\
\left(\mathrm{~cm}^{-1}\right)\end{array}$ & $\begin{array}{c}\text { TOC } \\
(\mathrm{mg} / \mathrm{L})\end{array}$ & $\begin{array}{c}\text { Chlorophyll-a } \\
\left(\mathrm{mg} / \mathrm{m}^{3}\right)\end{array}$ & $\begin{array}{c}\text { Cell density } \\
(\mathrm{cell} / \mathrm{mL})\end{array}$ & $\begin{array}{c}\text { Alkalinity } \\
(\mathrm{mg} / \mathrm{L})\end{array}$ \\
Value & $7.12 \sim 7.45$ & $2.54 \sim 7.12$ & $0.062 \sim 0.071$ & $2.11 \sim 3.12$ & $5.21 \sim 11.5$ & $96 \sim 260$ & $38 \sim 46$ \\
\hline
\end{tabular}

을 활용한 다양한 연구가 시도되었으나, 조류 발생정도를 반영한 연구는 미흡하였다. 이에 본 연구를 통해 응집처리 로 조류 제거시 적용할 수 있는 응집제의 종류와 주입량이 조류 밀도에 따라 달라질 수 있는지 조사하였다. 남조류 중 낙동강 수계에서 가장 빈번하게 발생되는 Microcystis를 ${ }^{19)}$ 연구대상으로 하였으며 조류 밀도별 단계(관심, 경계, 조류 대발생)로 구분하여 응집처리에 의한 제거 특성을 조사하 였다.

\section{2. 재료 및 방법}

\section{1. 조류 배양 및 원수}

실험에 사용된 조류는 낙동강에서 발생하는 유해 남조류 의 대표종인 Microcystis aeruginosa (이하 Microcystis)로 국 립낙동강생물자원관에서 분리 동정한 종을 분양받아 배 양하여 사용하였다. 배양을 위한 배지는 BG-11을 사용하 였으며 ${ }^{20)}$ 제조한 배지를 이용해 20 (배지) : 1 (조류)의 비율로 Culture Flask에 접종한 후 진탕 배양기에서 온도 $26^{\circ} \mathrm{C}$, 회 전속도 $110 \mathrm{rpm}$ 으로 설정하고 $40 \mathrm{~W}$ 의 백색 형광등 4 개를 조사하여 배양시켰다. 고농도로 배양된 Microcystis는 낙 동강에서 채수한 원수로 각각 희석하여 $10,000,100,000$, $1,000,000 \mathrm{cell} / \mathrm{mL}$ 농도로 응집 실험을 하였다. 희석에 사용 된 원수의 수질특성은 Table 1에 정리되어 있다.

\section{2. 응집 실험(Jar-Test)}

실험에 사용된 응집제는 국내 정수장에서 많이 사용하는 무기성 응집제인 Alum (Aluminum sulfate, $\mathrm{Al}_{2} \mathrm{O}_{3} 8 \%$, CAS 10043-01-37787-24-9)과 $\mathrm{PACl}$ (Poly aluminum chloride, $\mathrm{Al}_{2} \mathrm{O}_{3}$ $17 \%$, CAS 101707-17-9) 그리고 무독성으로 2차 오염을 일 으키지 않는 황토(Loess) ${ }^{21,22)}$ 와 일라이트(Illite)로 총 4가지 응집제를 대상으로 하여 Jar-Test를 진행하였다. Jar-Test는 조류 밀도 $(10,000,100,000,1,000,000 \mathrm{cell} / \mathrm{mL})$ 를 맞춘 원수 $(1 \mathrm{~L})$ 에 각 응집제를 농도별 $(0-150 \mathrm{mg} / \mathrm{L})$ 로 주입한 후 급속 교반(140 rpm) 1 분, 완속교반 $(40 \mathrm{rpm}) 15$ 분간 실시한 후 1 시 간 동안 침강시켜 상등액을 분취한 후 각 분석항목을 측정 하였다. 모든 응집 실험은 중복실험(duplicate)으로 하였다.

\section{3. 분석방법}

Jar-test 실험 시료에 대해 $\mathrm{pH}$, 탁도(Turbidity), 총유기탄소 (TOC), $\mathrm{UVA}_{254}$ (UVA at $254 \mathrm{~nm}$ ), 클로로필a (Chlorophyll-a), 조류 밀도 등을 분석하였다. $\mathrm{pH}$ 는 $\mathrm{pH}$ meter (Star A series,
Thermo Fisher Scientific, USA)로 측정하였고, 탁도는 탁 도계(HI98703, Hanna Instruments, USA)로 측정하였다. 유 기물 성분 분석을 위해 TOC는 총유기탄소분석기(TOC-L $\mathrm{CPH} / \mathrm{CPN}$, Shimadzu, Japan)로 분석하였고 $\mathrm{UVA}_{254}$ 는 $\mathrm{GF} / \mathrm{C}$ $(45 \mathrm{mmD})$ 로 여과한 후 흡광광도계(DR6000, HACH, USA) 로 측정하였다. 클로로필a (Chlorophyll-a)는 수질오염공정 시험기준(ES 04312.1a)에 따라 흡광광도계를 이용하여 측 정하여 계산하였다. 조류 밀도는 루골용액(Lugol's solution) $1 \mathrm{~mL}$ 를 떨어뜨린 후 일정시간 뒤에 수질오염공정시험기준 의 식물성플랑크톤-현미경계수법(ES 04705.1b)으로 측정하 였다. ${ }^{23)}$

\section{3. 결과 및 고찰}

\subsection{Microcystis 제거}

Fig. 1은 세 가지 다른 조류 밀도(목표 10,000, 100,000, $1,000,000 \mathrm{cell} / \mathrm{mL}$, 실측치 $9,950,102,000,991,000 \mathrm{cell} / \mathrm{mL}$ ) 를 가지는 낙동강 원수로 응집 실험한 결과 응집제 종류 및 주입량에 따른 Microcystis 제거율 변화를 나타낸 것이다. 전반적으로 응집제 종류와 관계없이 주입량을 증가시킬수 록 Microcystis 제거율이 증가하는 경향을 보였으며, 같은 주입량에서는 화학 응집제(PACl, Alum)의 Microcystis 제거 율이 광물 응집제(황토, 일라이트)의 제거율보다 높은 경향 을 나타냈다(Fig. 1).

조류 밀도 9,950 cell/mL (Fig. 1(A))의 경우 Alum $21 \mathrm{mg} / \mathrm{L}$ 주입 시 $55.2 \%$ 의 제거율을 나타내어 타 응집제 주입량 대 비 가장 효율적인 Microcystis 제거율을 보였으며, 주입량 $147.8 \mathrm{mg} / \mathrm{L}$ 에서 최대 $95.8 \%$ 의 제거율을 보였다. $\mathrm{PACl}$ 은 $143 \mathrm{mg} / \mathrm{L}$ 주입한 경우 Microcystis 제거율이 $98.0 \%$ 로 가장 높았으며 광물 응집제인 일라이트와 황토는 본 실험의 주입 량 범위 $(150 \mathrm{mg} / \mathrm{L})$ 내에서 최대 제거율이 각각 $39.1 \%$ 와 $16.6 \%$ 로 낮았다.

조류 밀도 $102,000 \mathrm{cell} / \mathrm{mL}$ (Fig. 1(B))의 경우 무기응집제 에 의한 Microcystis 최대 제거율(PACl 92.0\%, Alum 81.6\%) 은 조류 밀도 $9,950 \mathrm{cell} / \mathrm{mL}$ 인 경우 $(\mathrm{PACl} 98.0 \%$, Alum $95.8 \%)$ 에 비해 낮아졌으나, 응집제 주입량이 낮은 범위( 50 $\mathrm{mg} / \mathrm{L})$ 의 Microcystis 제거율은 오히려 상승하였다. 이러한 경향은 일라이트와 황토를 주입한 경우 더욱 뚜렷하게 나타 났다. 일라이트와 황토는 $102,000 \mathrm{cell} / \mathrm{mL}$ 에서 최대 제거율 도 각각 $62.2 \%$ 와 $41.8 \%$ 로 조류 밀도 $9,950 \mathrm{cell} / \mathrm{mL}$ 의 제거율 보다 증가하였다. 이러한 경향은 조류 밀도가 $9,950 \mathrm{cell} / \mathrm{mL}$ 

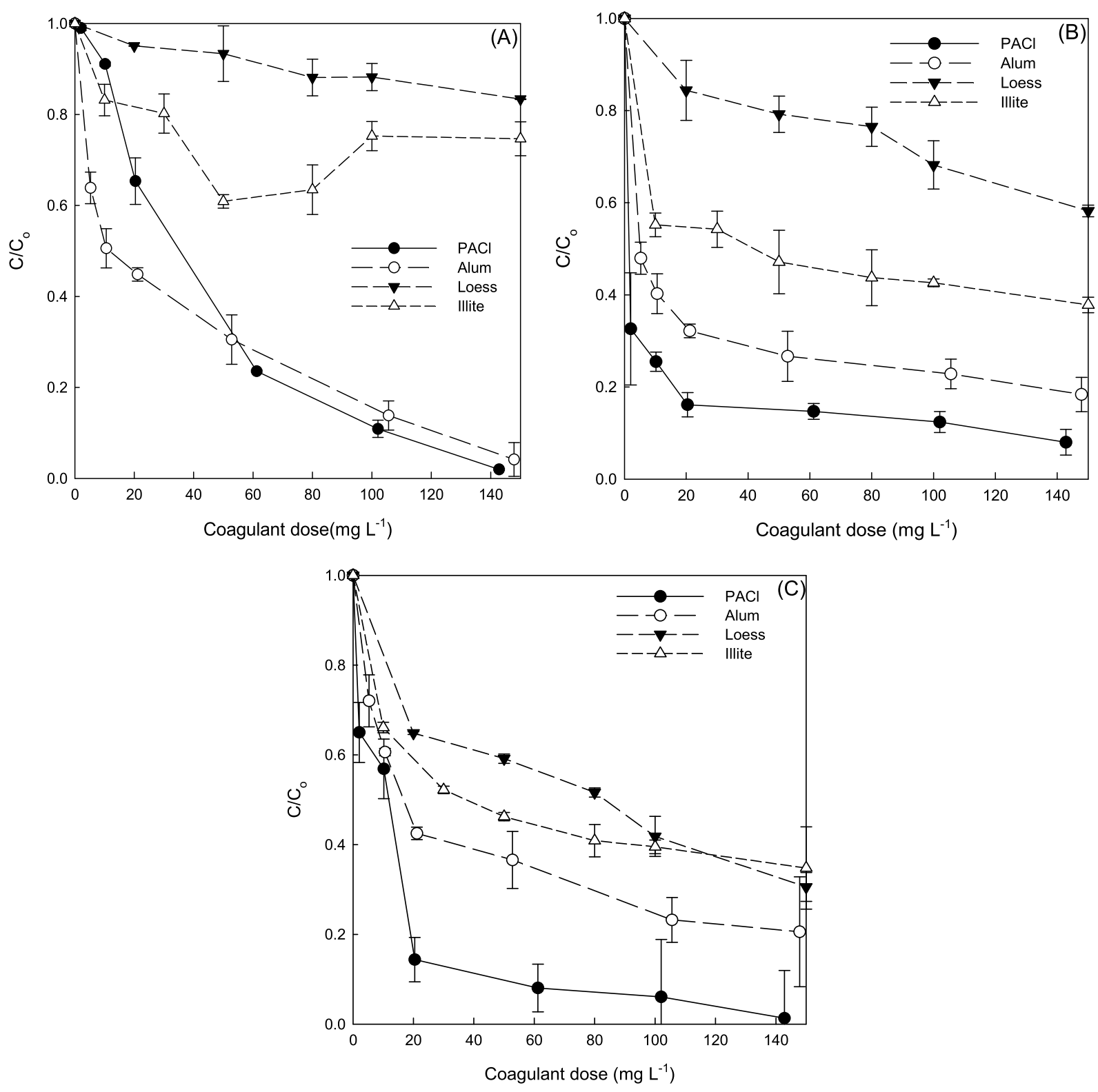

Fig. 1. Comparison of Microcystis removal by various coagulants in raw waters with three different cell densities: (A) 9,950 cell/mL, (B) $102,000 \mathrm{cell} / \mathrm{mL}$ and (C) $991,000 \mathrm{cell} / \mathrm{mL}$.

일 때에 비하여 $102,000 \mathrm{cell} / \mathrm{L}$ 인 경우 입자성 물질이 증가하 여 응집 효율이 보다 향상되어 나타난 것으로 판단된다. ${ }^{24)}$ 조류 밀도 991,000 cell/mL (Fig. 1(C))의 경우도 102,000 cell $/ \mathrm{mL}$ 의 결과와 마찬가지로 각 응집제별 최대주입량 주입 시 전반적으로 Microcystis 제거율(최대 제거율 $\mathrm{PACl} 98.7 \%$, Alum $79.42 \%$ )이 증가하였고 일라이트와 황토의 제거효율 이 향상되었다.

\section{2. 클로로필a 제거}

조류 밀도가 $9,950,102,000,991,000 \mathrm{cell} / \mathrm{mL}$ 가 되도록 Microcystis를 주입한 원수의 클로로필a 농도는 각각 26.40 , $40.58,201.52 \mathrm{mg} / \mathrm{m}^{3}$ 이었으며, 이는 낙동강에서 채수한 원
수의 클로로필a 농도 $8.21 \mathrm{mg} / \mathrm{m}^{3}$ (평균)은 원수 대비 3 24배 높은 수치였다. Fig. 2는 조류 밀도를 달리한 원수별 응집제 주입량에 따른 클로로필a 제거율을 나타낸 것이다. 조류 밀 도 $9,950 \mathrm{cell} / \mathrm{mL}$ 의 경우 전반적으로 응집제 주입량을 증가 시킬수록 클로로필a 제거율도 증가하였다(Fig. 2(A)). PACl 이 가장 높은 제거율을 나타냈는데, $20.4 \mathrm{mg} / \mathrm{L}$ 을 주입했 을 때 $83.3 \%$ 의 클로로필a 제거율을 보였으며, $147.8 \mathrm{mg} / \mathrm{L}$ 주입 시 $87.9 \%$ 까지 제거율이 증가하였다. Alum 주입 시 최 대제거율은 $72.7 \%$ 이었으며 일라이트와 황토는 최대제거율 이 각각 $56.4 \%, 38.6 \%$ 로 화학 응집제에 비해 상대적으로 낮았다.

조류 밀도 $102,000 \mathrm{cell} / \mathrm{mL}$ 의 경우 $\mathrm{PACl} 20.4 \mathrm{mg} / \mathrm{L}$ 주입 

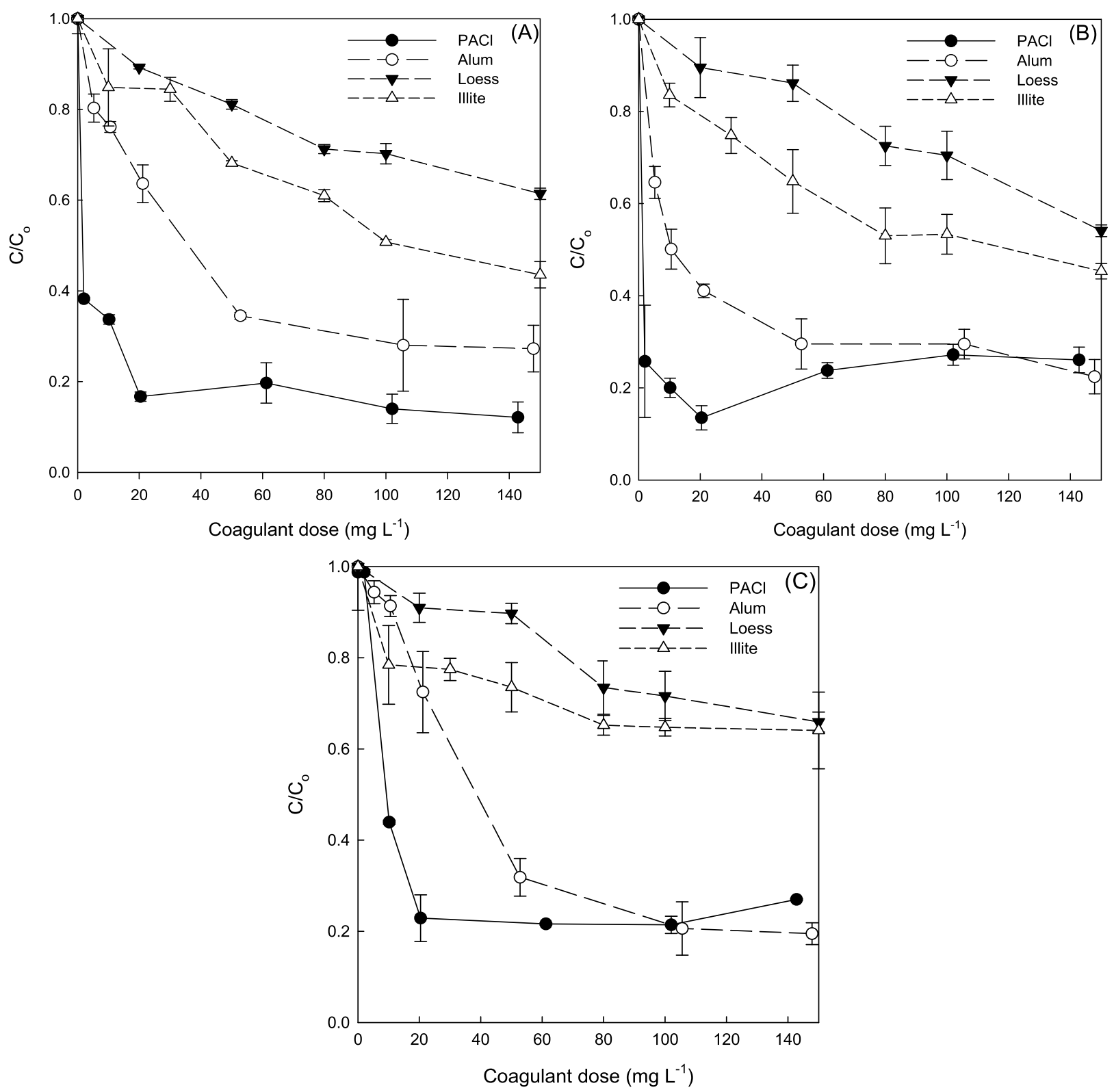

Fig. 2. Comparison of chlorophyll-a removal by various coagulants in raw waters with three different cell densities: (A) 9,950 cell/mL, (B) $102,000 \mathrm{cell} / \mathrm{mL}$ and (C) $991,000 \mathrm{cell} / \mathrm{mL}$.

시 $86.5 \%$ 로 가장 높은 제거율을 나타냈고 이후 $\mathrm{PACl}$ 의 주 입량을 증가시켜도 클로로필a 제거율이 더 이상 증가하지 않았다(Fig. 2(B)). Alum은 최대주입량 주입 시 $77.6 \%$ 까지 제거되었으며 일라이트와 황토는 조류 밀도 $9,950 \mathrm{cell} / \mathrm{mL}$ 와 비교해 클로로필a 제거율이 다소 감소하는 경향을 나타 냈다. 조류 밀도 $991,000 \mathrm{cell} / \mathrm{mL}$ 에서도 $\mathrm{PACl}$ 이 가장 효과 적인 제거효율을 나타내었다(Fig. 2(C)). PACl에 의한 클로 로필a 제거는 조류 밀도 $102,000 \mathrm{cell} / \mathrm{mL}$ 의 경우와 유사한 경향을 보이는 것을 확인할 수 있었는데, $20.4 \mathrm{mg} / \mathrm{L}$ 주입 시 $77.1 \%$ 까지 제거된 후 제거율의 변화가 거의 없었다.

원수의 조류 밀도와 관계없이 클로로필a의 제거율은 유사 한 경향을 나타냈는데, 화학응집제의 제거율이 광물 응집제
의 제거율에 비해 다소 높은 경향을 나타내는 것을 확인할 수 있었다. $\mathrm{PACl}$ 과 Alum은 적정 주입량에서 최대 제거율을 나타내고 주입량을 증가시켜도 제거율에 큰 변화가 없었다. 반면, 일라이트와 황토의 경우 주입량을 증가시킬수록 클로 로필a의 제거율도 지속적으로 증가하는 경향을 나타냈다. 이는 $\mathrm{PACl}$ 과 Alum은 이중층압축과 전하중화에 의한 작용 으로 적정 주입량에서 최대의 응집효율을 나타내었기 때문 으로 판단된다. ${ }^{4,14,25)}$

클로로필a는 조류 밀도를 간접적으로 나타내는 지표로 본 연구에서도 클로로필a 제거가 조류 밀도 제거와 비교하여 양 적 제거율은 낮지만 경향은 비슷하게 나타났었다. 보다 명확 한 관계를 규명하기 위하여 Microcystis 밀도 및 클로로필a 


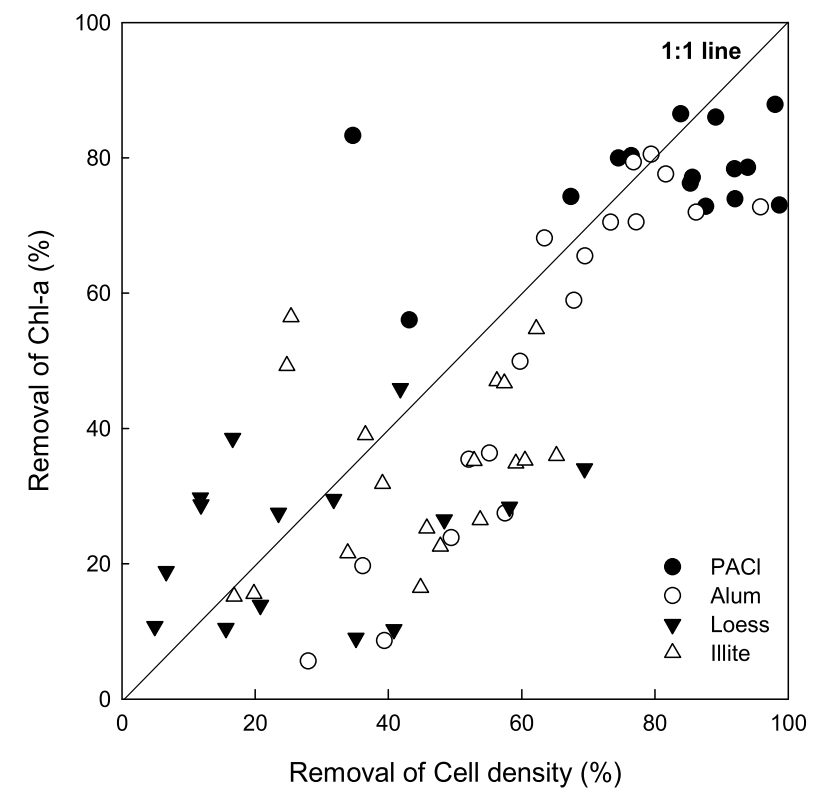

Fig. 3. Correlation between removals of cell density and chlorophyll-a.

제거율의 상관성을 비교하였다(Fig.3). 사용된 응집제를 모 두 포함한 결과에 대한 Microcystis 밀도 및 클로로필a 제거 율 간의 상관계수(r)는 0.8170 이었다. 이 결과를 응집제 종류 별로 세분하면 Alum이 $\mathrm{r}=0.9265$ 로 가장 높은 상관성을 보 였으며 $\mathrm{PACl}(\mathrm{r}=0.6539)$ 이 유의미한 상관관계를 나타냈다. 다만, 황토 $(\mathrm{r}=0.3036)$ 와 일라이트 $(\mathrm{r}=0.2961)$ 는 낮은 상관 관계를 나타냈다. 화학 응집제의 경우 응집제 주입에 따른 조류 밀도 제거를 클로로필a 제거경향으로 예측할 수 있는 반면, 광물 응집제를 사용할 때는 클로로필a 제거율로 조 류 밀도 제거를 간접적으로 예측하지 않도록 주의해야 할 것이다.

\section{3. 유기물 제거}

Microcystis 주입농도 $9,950 \mathrm{cel} / \mathrm{mL}$ 원수의 응집제 종류 및 주입량에 따른 유기물 제거율 변화를 Fig.4에 나타내었 다. Fig.4는 $\mathrm{UVA}_{254}$ 에 대한 결과인데 TOC의 결과도 제거율 이 5 20\% 정도 낮게 나타났을 뿐 유사한 경향을 보였다. 화학응집제인 $\mathrm{PACl}, \mathrm{Alum}$ 의 경우 $20 \mathrm{mg} / \mathrm{L}$ 에서 주입량 대 비 가장 효율적인 제거율을 나타내고 이후로는 제거율에 큰 차이가 없었다. 일라이트와 황토의 경우 주입량을 증가시킬수 록 유기물 제거율이 점차 증가하였는데, 각각 최대 $31 \%, 24 \%$ 의 제거율을 나타내며 화학응집제 대비 낮은 제거율을 나타 내었다. 이러한 경향은 $102,000 \mathrm{cell} / \mathrm{mL}$ 및 $991,000 \mathrm{cell} / \mathrm{mL}$ 의 유기물 제거 실험에서도 유사하게 나타났다. 조류 밀도를 달리한 원수의 유기물제거는 앞서 설명한 Microcystis 밀도 및 클로로필a 제거에 비해 낮은 제거율을 나타내는 것을 확인할 수 있었다. 이는 조류에서 기인한 용해성 유기물인 AOM (Algal-derived Organic Matter)과 조류내부 유기물질

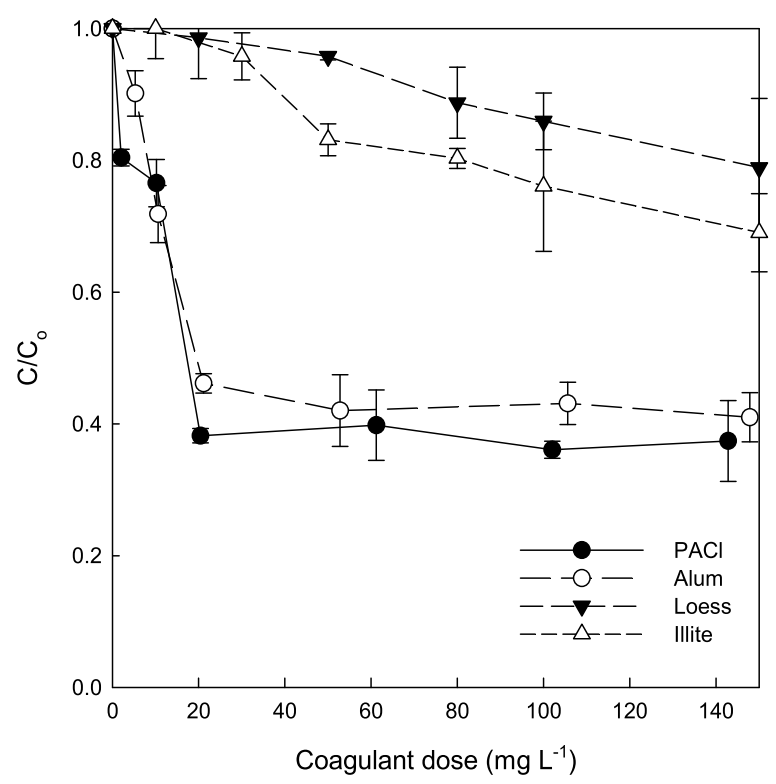

Fig. 4. Removal of $U_{V A} 25$ by various coagulants in raw water with a cell density of $9,950 \mathrm{cell} / \mathrm{mL}$.

인 IOM (Intercellular Organic Matter) 등이 응집처리로 제거 하는데 한계가 있다는 기존 연구의 결과와 유사하다. ${ }^{3,26-31)}$

\section{4. 결론}

본 연구는 낙동강 녹조현상의 주원인인 남조류 중 가장 많이 발생되는 Microcystis를 대상으로 하여 응집제 종류 및 주입량에 따른 조류 밀도별 제거 특성을 파악하기 위한 응 집실험을 진행하였고 다음과 같은 결론을 얻었다.

1) 응집제 종류와 관계없이 주입량이 증가할수록 Microcystis 제거율이 증가하는 경향을 보였으며, 같은 주입량에서는 $\mathrm{PACl}$ 과 Alum의 Microcystis 제거율이 일라이트와 황토의 제거율보다 높은 경향을 나타냈다. 조류 밀도가 낮은 경우 $(9,950 \mathrm{cell} / \mathrm{mL})$ 보다 높은 경우 $(102,000,991,000 \mathrm{cell} / \mathrm{mL})$ Microcystis가 입자성 물질로 작용해 응집에 의한 제거율 이 상승하였다.

2) $\mathrm{PACl}$ 과 Alum은 적정 주입량 $(20 \mathrm{mg} / \mathrm{L})$ 에서 클로로필a 의 최대 제거율을 나타내었고 주입량을 증가시켜도 제 거율에 큰 변화가 없었으나, 일라이트와 황토는 주입량 을 증가시킬수록 클로로필a의 제거율도 지속적으로 증 가하였다.

3) Microcystis 밀도와 클로로필a 제거율 간의 상관성 분석 결과, $\mathrm{PACl}$ 이나 Alum의 경우 응집제 주입에 따른 조류 밀도 제거를 클로로필a 제거 경향으로 예측할 수 있는 반면, 일라이트나 황토를 사용할 때는 클로로필a 제거 율로 조류 밀도 제거를 간접적으로 예측하는 지표로 삼 기에는 적합하지 않은 것으로 판단하였다. 


\section{Acknowledgement}

이 연구는 2018년 정부(과학기술정보통신부)의 재원으로 국가 과학기술연구회 창의형 융합 연구사업(No. CAP-18-07-KICT) 의 지원을 받아 수행되었습니다.

\section{References}

1. H. K. Park, Y. C. Seo, I. H. Cho, B. H. Park, Effect of chlorination on disinfection byproducts production and release of microcystins from bloom-forming algae, J. Korean Soc. Water Environ., 22(3), 513-520(2006).

2. H. Y. Hwang, J. J. Song, M. S. Kim, D. Y. Kim, A study on efficiency of wastewater treatment using microalgae: focusing on nutrients and flocculation, J. Korean Soc. Environ. Technol., 19(6), 563-569(2018).

3. M. K. Kim, B. R. Moon, T. K. Kim, K. D. Zoh, A study on production \& removal of microcystin, taste \& odor compounds from algal bloom in the water treatment processes, The Korean J. Public Health, 52(1), 33-42(2015).

4. B. J. Lee, H. C. Oh, J. H. Ahn, Y. M. Kim, H. J. Kang, S. K. Kim, Algae and nutrient control by using the mineralized coagulant, KSWST Jour. Wat. Treat., 26(2), 45-52(2018).

5. J. K. Kim, D. G. Kang, W. S. Yeo, H. H. Kim, Trends in algae removal technology and eco-friendly algae control technology, KSWST Jour. Wat. Treat., 25(1), 91-109(2017).

6. T. K. Kim, J. H. Choi, Removal of geosmin by combined treatment of pac and intermediate chlorination in the conventional wtp, J. Korean Soc. Environ. Eng., 37(1), 7-13(2015).

7. M. G. Lee, Y. K. Kim, D. G. Ra, Nitrogen and phosphorus removal by ferric chloride coagulation, J. Korean Soc. Environ. Technol., 15(3), 169-174(2014).

8. K. Doederer, D. Gale, J. Keller, Effective removal of MIB and geosmin using MBBR for drinking water treatment, Water Res., 149, 440-447(2019).

9. R. Henderson, S. A. Parsons, B. Jefferson, The impact of algal properties and pre-oxidation on solid-liquid separation of algae, Water Res., 42(8-9), 1827-1845(2008).

10. Han-River Water Environment Research Center National Institute of Environmental Research, Molecular biological characteristics of cyanobacteria originated off flavor in water(I), National Institute of Environmental Research(2018).

11. Environmental Microbiology Division Environmental Health Research Department National Institute of Environmental Research, A study on the production and behavior of cyanobacterial toxin, National Institute of Environmental Research(2007).

12. Y. A. Choi, N. S. Han, E. G. Lim, Y. M. Kim, C. J. Choun, B. H. Lee, Characteristics of cyanobacterial occurrence and concentration distribution of cyanotoxins in hoeya reservoir, J. Korean Soc. Environ. Eng., 35(12), 943-952(2013).
13. B. S. Jeon, J. S. Han, S. K. Kim, J. H. Ahn, H. C. Oh, H. D. Park, An overview of problems cyanotoxins produced by cyanobacteria and the solutions thereby, J. Korean Soc. Environ. Eng., 37(12), 657-667(2015).

14. C. J. Cheong, Removal of microalgae using inorganic coagulants in coagulation and sedimentation processes for water treatment, J. Korean Soc. Environ. Eng., 30(1), 85-89(2008).

15. A. Sukenik, Y. Viner-Mozzini, M. Tavassi, S. Nir, Removal of cyanobacteria and cyanotoxins from lake water by composites of bentonite with micelles of the cation octadecyltrimethyl ammonium(ODTMA), Water Res., 120, 165-173(2017).

16. Ministry of Environment, What is an algal bloom?(2016).

17. J. K. Shin, B. G. Kang, S. J. Hwang, Water blooms (green-tide) dynamics of algae alert system and rainfall-hydrological effects in Daecheong reservoir, Korean J. Ecology and Environment, 49(3), 153-175(2016).

18. Ministry of Environment, Algae Alert System(2018).

19. J. J. Yu, H. J. Lee, K. L. Lee, H. S. Lyu, J. W. Whang, L. Y. Shin, S. U. Chen, Relationship between distribution of the dominant phytoplankton species and water temperature in the Nakdong river, Korean J. Ecology and Environment, 47(4), 247-257(2014).

20. R. Y. Stanier, R. Kunisawa, M. Mandel, G. Cohen-Bazire, Purification and properties of unicellular blue-green algae (order chroococcales), Bacteriol Rev., 35(2), 171-205(1971).

21. M. R. Sengco, D. M. Anderson, Controlling harmful algal blooms through clay flocculation, J. Eukaryot. Microbiol., 51(2), 169-172(2004).

22. H. J. Park, S. H. Kim, W. S. Park, J. Y. Lee, J. A. Lee, The removal efficiency of microcystis spp. and its ecotoxicity using clay, J. Korean Soc. Water Environ., 30(3), 261-268(2014).

23. Ministry of Environment, Korean standard methods for water quality(2018).

24. H. Zou, G. Pan, H. Chen, X. Yuan, Removal of cyanobacterial blooms in Taihu lake using local soils II. effective removal of microcystis aeruginosa using local soils and sediments modified by chitosan, Environ. Pollut., 141(2), 201-205(2006).

25. Y. J. Park, S. S. Lee, H. R. Cho, Studies on the flocculation of algae with metal ions, J. Korean Soc. Environ. Eng., 37(8), 441-449(2015).

26. R. K. Mishra, B. P. Shaw, B. K. Sahu, S. Mishra, Y. Senga, Seasonal appearance of chlorophyceae phytoplankton bloom by river discharge off paradeep at orissa coast in the bay of bengal, Environ. Monit. Assess., 149(1-4), 261-273(2009).

27. C. W. Lee, C. W. Jung, S. W. Han, L. S. Kang, J. H. Lee, The removal of algae by oxidation and coagulation processes, J. Korean Soc. Environ. Eng., 23(9), 1527-1536(2001).

28. J. J. Rook, Formation of haloforms during chlorination of natural water, J. Water Treat. Exam, 23(2), 234-243(1974).

29. J. D. Plummer, J. K. Edzward, Effect of ozone on disinfection by-product formation of algae, Water Sci. Technol., 37(2), 49-55(1998). 
30. H. J. Son, J. M. Jung, H. S. Yeom, J. T. Choi, S. H. Jang, Formation of disinfection by-products from blue-green algae by chlorination, J. Environ. Sci. Int., 21(8), 1015-1021(2012).

31. S. J. Park, I. K. Cha, T. I. Yoon, Removal of algogenic organic matter in drinking water treatment process, J. Korean Soc. Environ. Eng., 27(4), 377-384(2005).

\section{Authors}

\section{Joo Eun Han}

Department of Environmental Engineering, Kumoh National Institute of Technology, Master Course Student, ORCID(1) 0000-0001-8739-1531

\section{Wontae Lee}

Department of Environmental Engineering, Kumoh National Institute of Technology, Professor, ORCID (1) 0000-0001-9660-4455 